\title{
Amplification and overexpression of the cyclin D1 gene in head and neck squamous cell carcinoma
}

\author{
X Wang, Z P Pavelic, Y-Q Li, L Wang, L Gleich, K Radack, J L Gluckman, \\ P J Stambrook
}

College of Medicine, University of Cincinnati,

231 Bethesda Avenue, Cincinnati, Ohio 45267-0521, USA:

Department of Cell Biology, Neurobiology and Anatomy

$\mathrm{X}$ Wang

P J Stambrook

Department of Otolaryngology, Head and Neck Surgery

Z P Pavelic

$\mathrm{Y}-\mathrm{Q} \mathrm{Li}$

L Wang

L Gleich

J L Gluckman

Department of Internal Medicine K Radack

Correspondence to: Peter J Stambrook PhD

Accepted for publication 27 June 1995.

\begin{abstract}
Aims-To determine cyclin D1 gene amplification and expression levels in head and neck squamous cell carcinoma (HNSCC) patients.

Methods-Total RNA and genomic DNA were isolated from 40 samples of HNSCC tissue and matched normal tissue and were hybridised with a cyclin D1 cDNA probe. Northern and Southern analyses were used to detect mRNA overexpression and cyclin D1 gene amplification, respectively.

Results-15 of the $40 \mathrm{HNSCC}$ samples examined (38\%) showed cyclin D1 gene amplification. Of these 15 samples, all 13 from which RNA was available showed increased cyclin D1 expression.

Conclusions-HNSCC patients with both amplification and overexpression of the cyclin D1 gene are at greater risk than patients who showed no cyclin D1 gene amplification; amplification and overexpression of the cyclin D1 gene may play an important role in the progression of HNSCC and in clinical outcome.

(f Clin Pathol: Mol Pathol 1995;48:M256-M259)
\end{abstract}

Keywords: cyclin D1, head and neck squamous cell carcinoma, gene amplification, mRNA overexpression, tumour progression.

Cyclins are central to the control of the eukaryotic cell cycle. When their expression is unregulated, they are considered likely participants in the oncogenic process. ${ }^{1-3}$ Within the cyclin gene family, the involvement of cyclin D1 in various human tumours has often been observed. ${ }^{4-20}$ Recently, the capacity of altered cyclin D1 gene expression to transform cells in vitro and in vivo has been demonstrated, ${ }^{2122}$ indicating that cyclin D1 indeed plays an important role in tumorigenesis.

The deregulation of cyclin D1 in tumours occurs as a consequence of either tumour specific gene translocation or amplification of chromosome locus 11q13, where the cyclin D1 gene resides. In the case of parathyroid adenoma and some B cell lymphomas, the cyclin D1 gene undergoes rearrangement. ${ }^{46}$ In contrast, amplification of this gene has been implicated in other types of human tumours including those of breast, ${ }^{7-10}$ oesophagus, ${ }^{11}$ lung, ${ }^{13}$ liver $^{1415}$ and urinary bladder, ${ }^{16}$ and in head and neck squamous cell carcinomas (HNSCC). ${ }^{77-20}$
Head and neck carcinomas account for 5$7 \%$ of new cases of cancer diagnosed annually and for about $3 \%$ of all cancer deaths. ${ }^{23}$ Over $90 \%$ of these tumours are squamous cell carcinomas. Epidemiological studies have indicated that tobacco is a major factor in the tumorigenesis of HNSCC, ${ }^{24}$ while alcohol, environmental exposure, and some viral infections may play a synergistic role. ${ }^{25}$ The molecular mechanisms operating in the malignant transformation of these carcinomas are still largely unknown. Although amplification of chromosome band $11 \mathrm{q} 13$, including int- 2 and hst-1 genes, has been found in HNSCC, ${ }^{1726-28}$ inconsistent and often absent expression of these genes ${ }^{1729}$ suggests that they do not play a key role in oncogenesis. Another possible target gene in the HNSCC is the cyclin D1 gene, which is overexpressed in HNSCC cell lines. ${ }^{718}$ However, cyclin D1 gene expression in HNSCC patients has not been evaluated systematically in relation to clinical outcome.

In this study we have examined the relation between gene amplification and mRNA overexpression of cyclin D1 in HNSCC patients. During the course of this work, a paper indicating that cyclin D1 gene amplification correlates with higher levels of mRNA in human laryngeal carcinoma was published..$^{20}$ Our investigation confirms these results and further indicates a poor prognosis for patients with cyclin D1 gene amplification.

\section{Methods}

PATIENTS AND TISSUES

Forty human HNSCC tissue samples were collected from patients who underwent surgery between March 1992 and May 1994. Adjacent normal mucosa was also obtained from the same patient. Of the $40 \mathrm{HNSCC}$ samples used in the study, 33 were primary and seven were recurrent carcinomas. The 33 primary $\mathrm{HN}$ SCCs included two stage II, nine stage III, and 22 stage IV carcinomas.

\section{DNA AND RNA ISOLATION}

Tissue was pulverised and ground to a fine powder with a pestle in a mortar partially filled with liquid nitrogen. Total RNA and high molecular weight DNA were isolated by guanidine isothiocyanate extraction and caesium chloride gradient centrifugation. ${ }^{30}$ 
Cyclin D1 gene amplification/overexpression and clinicopathological characteristics of patients with primary head and neck squamous cell carcinoma (a total of 19 patients) who underwent surgery from March 1992 to fuly 1993

\begin{tabular}{|c|c|c|c|c|c|c|c|}
\hline No & Age/sex & Site & $T N M$ & $\begin{array}{l}\text { Clinical } \\
\text { stage }\end{array}$ & $\begin{array}{l}\text { Gene } \\
\text { amplification }\end{array}$ & $\begin{array}{l}m R N A \\
\text { overexpression }\end{array}$ & ${ }^{*}$ Aliveldead \\
\hline 2 & $69 / \mathrm{M}$ & Hypopharynx & $\mathrm{T} 4 \mathrm{~N} 2 \mathrm{M} 0$ & IV & + & + & Dead \\
\hline 4 & $65 / \mathrm{F}$ & Subglottic & T3NOMO & III & - & & Alive \\
\hline 5 & $54 / \mathrm{F}$ & Oral cavity & T4N2M0 & IV & + & unavailable & Dead \\
\hline 6 & $60 / \mathrm{F}$ & Oral cavity & T2N2M0 & IV & $\stackrel{+}{-}$ & - & Alive \\
\hline $\begin{array}{l}0 \\
7\end{array}$ & $\begin{array}{l}\text { Oov/M } \\
76 / M\end{array}$ & Oropharynx & T2N1M0 & III & $=$ & $z$ & Dead \\
\hline 8 & 57/M & Hypopharynx & T3N2M0 & IV & - & - & Dead \\
\hline 9 & $74 / \mathrm{M}$ & Oral cavity & T3NOMO & III & + & + & Dead \\
\hline 11 & $49 / M$ & Oral cavity & T4NOM0 & IV & - & - & Dead \\
\hline 12 & $53 / \mathrm{F}$ & Subglottic & T3NOMO & III & - & - & Alive \\
\hline 13 & 50/M & Parapharynx & T4N1M0 & IV & + & + & Alive \\
\hline 16 & $56 / \mathrm{M}$ & Oropharynx & $\mathrm{T} 4 \mathrm{~N} 2 \mathrm{M} 0$ & IV & + & + & Dead \\
\hline 17 & 40/M & Supraglottic & T2N1M0 & III & + & + & Alive \\
\hline 18 & $72 / M$ & Supraglottic & T3N2M0 & IV & + & + & Dead \\
\hline 19 & $54 / M$ & Oropharynx & T3N2M0 & IV & - & - & Alive \\
\hline 21 & $71 / M$ & Supraglottic & T2NOMO & II & $=$ & - & Alive \\
\hline 23 & $68 / M$ & Hypopharynx & T4N1M0 & IV & $=$ & $=$ & Alive \\
\hline 24 & 70/M & Oropharynx & T2NOMO & II & - & - & Alive \\
\hline & $47 / M$ & Hypopharynx & T4NOMO & IV & + & + & Dead \\
\hline 27 & 60/M & Oropharynx & T3N1M0 & IV & - & - & Alive \\
\hline
\end{tabular}

TNM: staging system for classification of head and neck cancers. Extent of primary cancer (T), status of regional lymph nodes $(\mathrm{N})$, absence or presence of metastatic spread $(\mathrm{M})$.

" ": with cyclin D1 gene amplification or mRNA overexpression; “-": without gene amplification or overexpression

*Alive: of surviving patients, follow up was 10 to 23 months (average 18 months).

\section{SOUTHERN ANALYSIS}

A $10 \mu \mathrm{g}$ sample of genomic DNA was digested to completion with EcoRI (Life Technology). The digested DNA was then separated on a
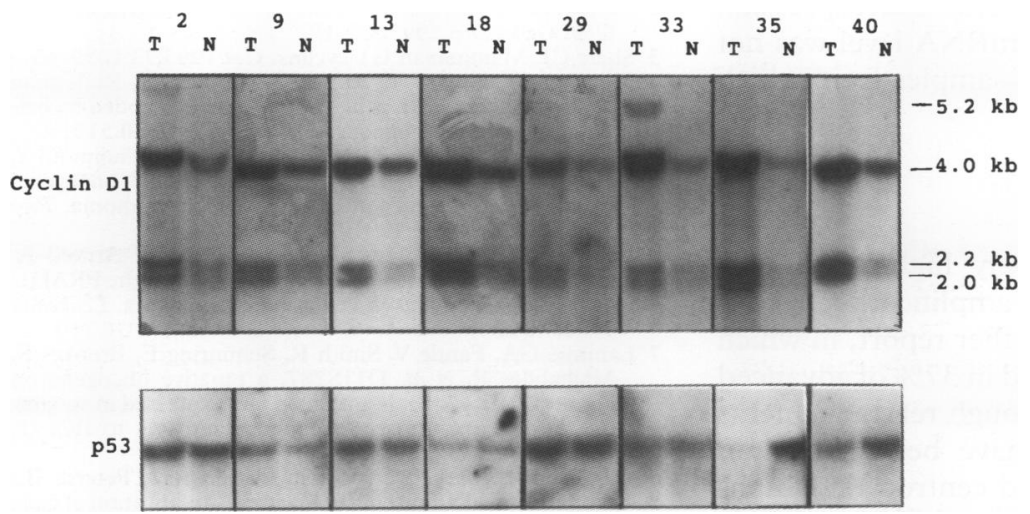

Figure 1 Amplification of cyclin D1 gene from eight representative head and neck carcinomas (HNSCC). T=DNA from HNSCC; $N=D N A$ from normal mucosa. Genomic DNA (10 $\mu \mathrm{g})$ from each of the numbered specimens was digested with EcoRI and analysed by Southern blotting with a cyclin D1 cDNA probe and a p53 cDNA probe as described in Methods. The size of each band is indicated on the right. Tumours 2 and 33 showed an extra $5 \cdot 2 \mathrm{~kb}$ band.
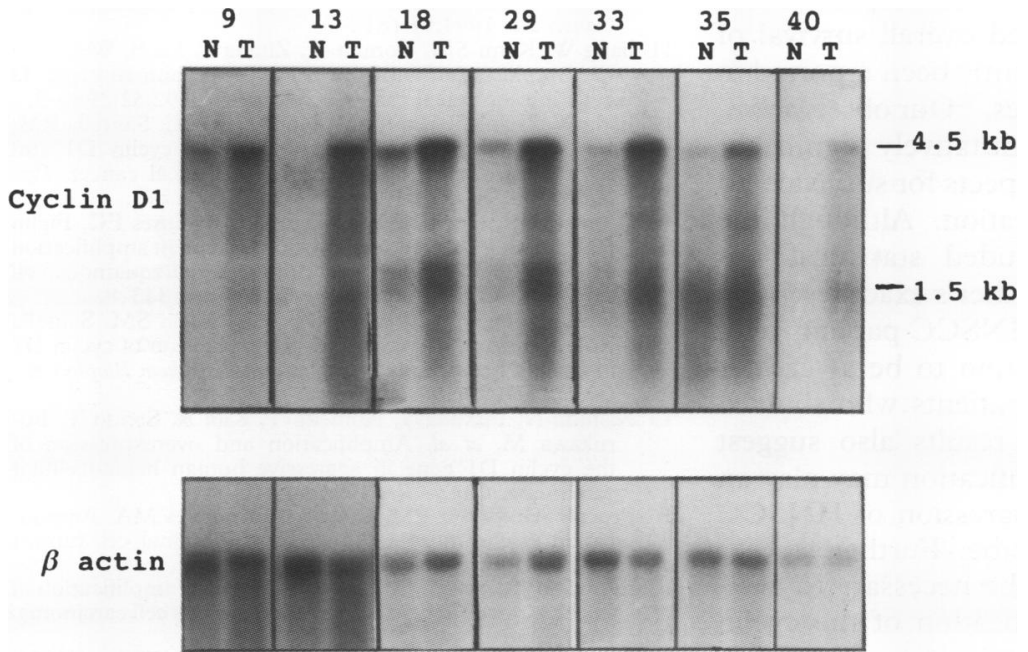

Figure 2 Overexpression of cyclin D1 gene from seven representative head and neck carcinomas (HNSCC). T=RNA from HNSCC; $N=R N A$ from normal mucosa. Total $R N A(5 \mu g)$ from each of the numbered specimens was analysed by northern blotting with a cyclin D1 cDNA probe and a $\beta$ actin cDNA probe as described in Methods. The size of each band is indicated on the right.
$0 \cdot 8 \%$ agarose gel and transferred to a Zetabind membrane (CUNO). The membrane was prehybridised at $65^{\circ} \mathrm{C}$ in $6 \times \mathrm{SSC}(\mathrm{NaCl} /$ sodium citrate), $5 \times$ Denhard's solution, $0.5 \%$ sodium dodecyl sulphate (SDS) (wt/vol), and $100 \mathrm{mg} /$ $\mathrm{ml}$ denatured salmon sperm DNA. The human cyclin D1 cDNA probe (provided by Dr D Beach) was labelled with ${ }^{32} \mathrm{P}$ using a Prime-IT II random primer labelling kit (Strategene) and was added to the prehybridisation solution. After hybridisation, the membrane was washed twice with $2 \times$ SSC, $0.1 \%$ SDS at room temperature for $30 \mathrm{~min}$, and twice with $0.1 \times \mathrm{SSC}$, $0 \cdot 1 \% \mathrm{SDS}$ at $60^{\circ} \mathrm{C}$ for $20-30 \mathrm{~min}$. The membrane was then autoradiographed. After removing the cyclin D1 cDNA probe, the membrane was reprobed with a p53 cDNA probe (provided by Dr D Givol) as a single copy internal control to normalise possible variation in loading or transfer of DNA.

\section{NORTHERN ANALYSIS}

A $5 \mu \mathrm{g}$ aliquot of total RNA from each sample was fractionated on a $1 \cdot 2 \%$ agarose gel after denaturing with glyoxal/dimethylsulphoxide. ${ }^{31}$ The RNA was transferred and hybridised as described above. Washes of membranes were carried out at room temperature in $1 \times$ SSC, $0.1 \% \mathrm{SDS}$ for $15 \mathrm{~min}$ twice, and at $60^{\circ} \mathrm{C}$ in $0 \cdot 2 \times$ SSC, $0 \cdot 1 \%$ SDS for 20 min twice. The human $\beta$ actin cDNA probe was used as an internal control for northern analysis.

\section{Results}

The cyclin D1 cDNA probe detected three EcoRI fragments of $4 \cdot 0,2 \cdot 2$, and $2 \cdot 0 \mathrm{~kb}$ on Southern blots. In our study cyclin D1 gene amplification was found in $15(38 \%)$ of the $40 \mathrm{HN}$ SCC samples collected. The degree of amplification varied from two- to 18 -fold. We also observed two interesting cases of HNSCC which showed not only gene amplification but also an extra $5 \cdot 2 \mathrm{~kb}$ band on the Southern blot, suggestive of cyclin D1 gene rearrangement (fig 1). 
For those patients (total of 19) who underwent surgery from March 1992 to July 1993 and had primary tumors with amplified cyclin D1, only $25 \%$ (two out of eight) are alive (table). In contrast, seven of 11 patients (64\%) whose tumors did not manifest cyclin D1 gene amplification have survived an average of one and a half years (table).

In order to determine the frequency with which the cyclin D1 gene is overexpressed, we examined the level of cyclin D1 transcription by northern analysis. A major transcript of $4.5 \mathrm{~kb}$ as well as a minor one of $1.5 \mathrm{~kb}$ were detected with the cyclin D1 probe. Of the 15 HNSCC samples with cyclin D1 amplification, all 13 with available RNA showed increased cyclin D1 expression when compared to their normal mucosa counterparts (fig 2 ). The overexpression ranged from two- to 16-fold. The two samples with an extra $5 \cdot 2 \mathrm{~kb}$ EcoRI band did not show a dramatic increase in expression of cyclin D1. Despite the fact that cyclin D1 overexpression was found in every case of $\mathrm{HN}$ SCC with gene amplification, the degree of amplification and overexpression did not seem to correlate fully. The cyclin D1 mRNA level of the $25 \mathrm{HNSCC}$ samples without gene amplification was also examined. Overexpression of cyclin D1 gene at the mRNA level was not detected in any of the 22 samples from which RNA was available.

\section{Discussion}

Our finding of a relatively high percentage $(38 \%)$ of cyclin D1 gene amplification is consistent with that from another report, in which amplification was recorded in $37 \%$ of advanced laryngeal tumours. ${ }^{20}$ Although rearrangements in the cyclin D1 gene have been shown in parathyroid adenoma ${ }^{4}$ and centrocytic lymphoma ${ }^{56}$ none has been reported in HNSCC. It would therefore be informative to investigate further the two cases which showed an extra $5.2 \mathrm{~kb}$ band on Southern blotting, to establish whether or not the rearrangement was indeed involved in some of the HNSCC cases.

The association between overexpression of cyclin D1 and a shortened overall survival of HNSCC patients has recently been reported in immunohistological studies. ${ }^{32}$ Our observation, however, suggests a quantitatively significant relationship between prospects for survival and cyclin D1 gene amplification. Although the small sample size precluded statistical significance ( $\mathrm{p}=0 \cdot 170$ by Fisher's exact test), the data suggest a trend for HNSCC patients with cyclin D1 gene amplification to be at greater risk of early death than patients who showed no amplification. These results also suggest that cyclin D1 gene amplification may play an important role in the progression of HNSCC and in the clinical outcome. Further studies with larger numbers will be necessary to evaluate the extent of amplification of the cyclin D1 gene in relation to prognosis.

The mechanism by which overexpression of the cyclin D1 gene affects the progression of HNSCC is not well understood. Overexpression may, by itself or in combination with other oncogene products, contribute to increased cellular proliferation. ${ }^{2133-37}$ It has been suggested that increased expression of cyclin D1 may provide a growth advantage for tumour cells because cells overexpressing this protein have a shortened G1 phase and less dependence on growth factors in vitro. ${ }^{33-36}$ It has also been reported that overexpression of the cyclin D1 gene may induce cellular transformation in cooperation with other oncogenes. ${ }^{21}{ }^{37}$ Further, this effect seems to be mediated through the capacity of cyclin D1 to overcome the inhibitory effect of retinoblastoma (RB) protein on cell cycle progression. ${ }^{21}$ Indeed, it has been found that in oesophageal cancer overexpression of cyclin D1 is associated with persistent expression of $\mathrm{RB}$ protein, whereas normal cyclin D1 expression appears to be associated with loss of $\mathrm{RB}$ expression. ${ }^{12}$ In view of these findings, we are currently investigating whether or not expression of RB is altered in HNSCC. ${ }^{38}$

We thank Ms Ljiljana Pavelic for collecting the tissues and Nancy Nichols for her secretarial assistance. This work was supported in part by NIH training grant CA 59268 (to XW).

1 Hunter T, Pines J. Cyclins and cancer. Cell 1991;66:1071-4.

2 Motokura T, Arnold A. Cyclin D and oncogenesis. Curr Opin Genet Dev 1993;3:5-10.

3 Sherr CJ. Mammalian G1 cyclins. Cell 1993;73:1059-65.

4 Motokura T, Bloom T, Kim HG, Juppner H, Ruderman $J$, Kronenberg HM, et al. A novel cyclin encoded by bclJV, Kronenberg HM, et al. A novel cyclin encoded by bct-

5 Rosenberg CL, Wrong E, Petty EM, Balf AE, Tsujimoto Y, Harris NL, et al. PRAD1, a candidate BCL-1 oncogene: mapping and expression in centrocytic lymphoma. Proc Natl Acad Sci USA 1991;88:9638-42.

6 Williams ME, Swerdlow SH, Rosenberg CL, Arnold A. Chromosome 11 translocation breakpoints at the PRAD1/ cyclin D1 gene locus in centrocytic lymphoma. Leukemia 1993;7:241-5.

7 Lammie GA, Fantle V, Smith R, Schuuring E, Brookes S, Michalides R, et al. D11S287, a putative oncogene on chromosome $11 \mathrm{q} 13$, is amplified and expressed in squamous cell and mammary carcinomas and link to BCL-1. Ous cell and mammary carc

8 Schuuring E, Verhoeven E, van Tinteren H, Peterse JL, Nunnink K, Thunnisen FBJM, et al. Amplification of gene within the chromosome 11 q13 region is indicative of poor prognosis in patients with operable breast cancer. Cancer Res 1992;52:5229-34.

9 Buckley MF, Sweeney KJE, Hamilton JA, Sini RL, Manning DL, Nicholson RI, et al. Expression and amplification of cyclin D1 genes in human breast cancer. Oncogene 1993; 8:2127-33.

10 Gillett C, Fantle V, Smith R, Fisher C, Bartek J, Dickson $\mathrm{C}$, et al. Amplification and overexpression of cyclin D1 in breast cancer detected by immunohistochemical staining. Cancer Res 1994;54:1812-7.

11 Jiang W, Kahn SM, Tomita N, Zhang Y, Lu S, Weinstein IB. Amplification and expression of the human cyclin D gene in esophageal cancer. Cancer Res 1992;52:2980-3.

12 Jiang W, Zhang Y, Kahn SM, Hollstesin MC, Santella RM, Lu S, et al. Altered expression of the cyclin D1 and retinoblastoma genes in human esophageal cancer. Proc Natl Acad Sci USA 1993;90:9026-30.

13 Berenson JR, Koga H, Yang J, Pearl J, Holmes EC, Figlin $R$, The Lung Cancer Study Group. Frequent amplification of the bcl-1 locus in poorly differentiated squamous cell carcinoma of the lung. Oncogene 1990;5:1343-8.

14 Zhang Y, Jiang W, Chen CJ, Lee SC, Kahn SM, Santella RM, et al. Amplification and overexpression of cyclin D1 in human hepatocellular carcinoma. Biochem Biophys Res in human hepatocellular carcir

15 Nishida N, Fukuda Y, Komeda T, Kita R, Sando T, Furukawa $M$, et al. Amplification and overexpression of the cyclin D1 gene in aggressive human hepatocellular carcinoma. Cancer Res 1994;54:3107-10.

16 Procter AJ, Coom LM, Cairns JP, Knowles MA. Amplification at chromosome $11 \mathrm{q} 13$ in transitional cell tumors of the bladder. Oncogene 1991;6:789-95.

17 Berenson JR, Yang J, Mickel RA. Frequent amplification of the bcl-1 locus in head and neck squamous cell carcinoma. Oncogene 1989;4:1111-9.

18 Schurring E, Verhoeven E, Mooi WJ, Michalides RJAM. Identification and cloning of two overexpressed genes, U21B31/PRAD1 and EMS1, within the amplified chromosome $11 \mathrm{q} 13$ region in human carcinomas. Oncogene 1992;7:355-61.

19 Williams ME, Gaffey MJ, Lawrence MW, Wilczynski SP, Schuuring E, Levine PA. Chromosome $11 \mathrm{q} 13$ am- 
plification in head and neck squamous cell carcinoma. Arch Otolaryngol Head Neck Surg 1993;119:1238-43.

20 Jares P, Fernandez PL, Campo E, Nadel A, Bosch F, Aiz $\mathrm{G}$, et al. PRAD1/Cyclin D1 gene amplification correlates with messenger RNA overexpression and tumor progression in human laryngeal carcinomas. Cancer Res 1994;54: 4813-7.

21 Hinds PW, Dowdy SF, Eaton EN, Arnold A, Weinberg RA. Function of a human cyclin gene as an oncogene. Proc Futl Acad Sci USA 1994;91:709-13.

22 Wang T, Cardiff RD, Zuberberg L, Lee E, Arnold A, Schmidt EV. Mammary hyperplasia and carcinoma in MMTV-cyclin D1 transgenic mice. Nature 1994;369:669 71 .

23 Canadian Cancer Society. Canadian cancer statistics. Toronto, 1988:3.

24 Wynder EL, Bross IJ. Aetiological factors in mouth cancer; an approach to its prevention. Br 7 Cancer 1957;10:113743.

25 Rothman KJ. The effect of alcohol consumption on risk of cancer of the head and neck. Laryngoscope 1978;88:51-2.

Z C DJ, Casey G, Cline MJ. Amplification of human int2 in breast cancers and squamous carcinomas. Oncogene 1988;2:279-82.

27 Sommers KD, Cartwright SL, Schechter GL. Amplification of the int-2 gene in human head and neck squamous cell carcinomas. Oncogene 1990;5:915-20.

28 Leonard JH, Kearsley JH, Chenevix-Trench G, Hayward NK. Analysis of gene amplification in head and neck squamous cell carcinomas. Int $\mathcal{F}$ Cancer 1991;48:511-5.

29 Faust JB, Meeker TC. Amplification and overexpression of bcl-1 gene in human solid tumor cell lines. Cancer Res 1992;52:2460-3.
30 Davis LG, Dibner MD, Batte JF. Basic methods in molecular biology. New York: Elsevier, 1986.

31 Sambrook J, Fritsch EF, Maniatis T. Molecular cloning: a laboratory manual. Cold Spring Harbor: Cold Spring Harbor Laboratory, 1989.

32 Michalides R, van Veelen N, Hart A, Loftus B, Wientiens E Balm A Overexpression of cyclin D1 correlates with recurrence in a groups of forty-seven operable squamous 55:975-8.

33 Baldin V, Lukas J, Marcote MJ, Pagano M, Draetta G. Cyclin D1 is a nuclear protein required for cell cycle progression in G1. Genes Dev 1993;7:812-21.

34 Jiang W, Kahn SM, Zhou P, Zhang Y, Cacace AM, Infante $\mathrm{AS}$, et al. Overexpression of cyclin D1 in rat fibroblasts causes abnormalities in growth control, cell cycle progression and gene expression. Oncogene 1993;8:3447-57.

35 Ouelle DE, Ashmum RA, Schurtleff SA, Kato JY, Barsagi $\mathrm{D}$, Roussell MF, et al. Overexpression of mouse D-type cyclins accelerates $\mathrm{Gl}$ phase in rodent fibroblasts. Gemes Dev 1993;7:1559-71.

36 Resnitzky D, Gossen M, Bujard H, Reed SI. Acceleration of the G1/S phase transition by expression of cyclin D1 of the Gl/S phase transition by expression of cyclin D1 and $\mathrm{E}$ with

37 Lovec H, Sewing A, Lucibello FC, Muller R, Moroy T. Oncogenic activity of cyclin D1 revealed through cooperation with Ha-ras: link between cell cycle control and malignant transformation. Oncogene 1994;9:323-6.

38 Pavelic ZP, Lasmar M, Pavelic LJ, Stambrook PJ, Gluckman JL. Altered expression of retinoblastoma gene in human oral cavity squamous cell carcinoma. Proc Am Assoc Cancer Res 1995;36:639. 